\title{
Implementasi Manajemen Mutu Pendidikan Islam Di Madrasah Aliyah Negeri I Tanjung Pandan Kabupaten Belitung
}

\author{
Suparta \\ Program Pascasarjana \\ STAIN Syaikh Abdurrahman Siddik Bangka Belitung \\ Bangka, Indonesia \\ partasuparta@yahoo.co.id
}

\begin{abstract}
Implementation of Quality Management of Islamic Education in MAN I Tanjung Pandan has been done with the maximum. Efforts to improve the quality of education in this school began from the improvement of human resources standards both in the form of educators and learners and educational personnel. The manifestation of this improvement of human resources by implementing the quality standard of education that has been formulated based on Quality Management Principles of Education. In addition to human resources improvement is also seen in curriculum management, learning and classroom management and facilities management and infrastructure. On the basis of some specified managerials then all Teachers, Students and Educational Personnel must implement. If not perform in accordance with applicable procedures and regulations then be subject to disciplinary strikes both on the Educator and the Learners.
\end{abstract}

Keywords: Implementation, Management, Quality, Education, Islam

Abstrak

Implementasi Manajemen Mutu Pendidikan Islam di MAN I Tanjung Pandan sudah dilakukan dengan maksimal. Usaha untuk meningkatkan mutu pendidikan di Sekolah ini di mulai dari peningkatan standar sumber daya Manusia baik berupa pendidik maupun peserta didik dan tenaga kependidikan. Wujud dari peningkatan SDM ini dengan cara melaksanakan standar mutu pendidikan yang telah disusun berdasarkan Prinsip-prinsip Manajemen Mutu Pendidikan. Selain berupa SDM peningkatan juga terlihat pada manajemen Kurikulum, Manajemen pembelajaran dan kelas serta manajemen sarana dan prasarana. Atas dasar beberapa manajerial yang sudah ditentukan tersebut maka seluruh Guru, Siswa dan Tenaga kependidikan harus melaksanakan. Bila tidak melaksanakan sesuai dengan prosedur dan peraturan yang berlaku maka dikenakan teguran disiplin baik pada Pendidik maupun pada Peserta Didik.

Kata Kunci: Implementasi, Manajemen, Mutu, Pendidikan, Islam

\section{A. Pendahuluan}

Mulyasa mengungkapkan sedikitnya terdapat tiga syarat utama yang harus diperhatikan dalam pembangunan pendidikan agar dapat berkontribusi terhadap peningkatan kualitas sumber daya manusia (SDM), yakni: Pertama, sarana gedung. Kedua, buku yang berkualitas. Ketiga, guru dan tenaga kependidikan yang Profesional. ${ }^{1}$ Sebagaimana diketahui, bahwa salah satu prioritas pembangunan pendidikan nasional dalam kaitannya dengan pengembangan kualitas sumber daya manusia ialah menyangkut peningkatan mutu setiap jenis dan jenjang pendidikan.

${ }^{1}$ Mulyasa, Menjadi Guru Profesional, (Bandung: Remaja Rosdakarya, Cet. III, 2005), 03 
Dalam rangka peningkatan mutu tersebut ada tiga faktor utama yang menjadi titik perhatian, yaitu; (1) Kecukupan sumber-sumber pendidikan untuk menunjang proses pendidikan, dalam arti kecukupan penyediaan jumlah dan mutu guru serta kependidikan lainnya; (2) Mutu proses pendidikan itu sendiri, dalam arti kurikulum dan pelaksanaan pengajaran untuk mendorong para siswa belajar lebih efektif; dan (3) Mutu output dari proses pendidikan, dalam arti ketrampilan dan pengetahuan yang telah di peroleh para siswa. $^{2}$

Tantangan besar yang dihadapi oleh seluruh bangsa Indonesia pada era globalisasi ini adalah ketatnya kompetisi diberbagai bidang. Kompetisi ini akan memasuki seluruh dimensi kehidupan dan menjamah wilayah geografis di berbagai belahan dunia. Apabila ingin menjadi survive atau bahkan menjadi pemenang dalam era kompetitif ini, kepemilikan daya saing menjadi prasyarat mutlak yang tidak dapat ditawar lagi. Pendidikan Islam merupakan salah satu bidang yang tidak dapat melepaskan diri dari tantangan peningkatan mutu secara berkelanjutan. Mutu pendidikan harus ditingkatkan menjadi lebih baik, karena sebagai kunci sukses yang harus dimiliki dan merupakan daya saing yang paling efektif.

Kebutuhan dan harapan masyarakat (community needs and wants) akan mutu pelayanan pendidikan yang baik tampaknya menjadi faktor pemicu utama inovasi manajemen pendidikan. Keputusan institusional (institutional decisions) yang dibuat oleh kepala madrasah dan staf untuk meningkatkan mutu pelayanan internal (di dalam lembaga pendidikan) dan eksternal (hubungan madrasah dengan masyarakat) akan sangat mempengaruhi proses pembuatan keputusan inovatif dalam bidang manajemen pendidikan. Kegiatan pendidikan dan pengajaran di madrasah akan berjalan baik, jika ditunjang oleh manajemen pendidikan yang memadai.

Satu hal hingga saat ini masih menjadi fokus pemikiran para ahli manajemen pendidikan adalah bagaimana menyeimbangkan antara produk kerja inovasi manajemen pendidikan Islam dan aplikasinya di madrasah-madrasah. Mereka sepakat bahwa inovasi manajemen pendidikan dapat dibuat dengan menggunakan logika deduktif dari proses inquiry, berdasarkan penelitian eksperimental atau penelitian empiris tertentu. Namun demikian pada tingkat aplikasi, ternyata unsur-unsur seni (art) dan keprigelan (craft) dalam kinerja manajemen pendidikan tidak sepenuhnya menujukkan perpaduan yang serasi ${ }^{3}$.

\section{B. Implementasi Manajemen SDM}

1. Bebas Mengikuti Pelatihan Ilmiah

Berdasarkan hasil wawancara dengan para Guru Bidang Studi MAN I Tanjung Pandan, mereka mengatakan bahwa mereka diberikan kebebasan untuk mengikuti pertemuan ilmiah. Adapun pertemuan ilmiah yang biasa diikuti berupa seminarseminar, lokakarya, workshop, dan beberapa pelatihan terutama pelatihan Kurikulum terbaru. Dengan demikian diharapkan ke depan SDM yang ada di sekolah ini semakin baik dan maju sesuai dengan yang diharapkan ${ }^{4}$.

Semakin sering para guru mengikuti peretemuan ilmiah maka kompetensi keilmuan yang dimiliki oleh para guru akan semakin bertambah. Hal ini membuktikan bahwa ghirah atau semangat belajar para guru di Madrasah Aliyah Negeri I Tanjung Pandan sangat baik. Guru memang tidak harus mengetahui segalanya akan tetapi untuk mengetahui segalanya bagi guru adalah sangat penting.

2 Muhaimin, Arah Baru Pengembangan Pendidikan Islam, Pemberdayaan Pengembangan Kurikulum Hingga Redefinisi Islamisasi Pengetahuan, (Bandung: Nuansa, 2003), 204

3 Danim, S., Visi Baru Manajemen Sekolah dari Unit Birokrasi ke Lembaga Akademik. (Jakarta: Bumi Aksara, 2006) h.61

${ }^{4}$ Wawancara dengan guru bidang studi di ruang Guru Madrasah Aliyah Negeri Tanjung Pandan, Kabupaten Belitung, pada tanggal 2 Juni 2016 pada pukul 10.00 WIB. 
Maka agar mendekati pengetahuan yang sempurna salah satunya dengan cara membebaskan para guru untuk terus mengikuti pertemuan-pertemuan ilmiah baik yang diselenggarakan secara lokal, nasional maupun internasional. Dengan demikian sekolah ini dapat memiliki guru-guru yang berprestasi.

2. Bebas Melakukan Pengembangan Kompetensi Keilmuan

Paling tidak ada empat kompetensi guru yang harus dikuasai dan dikembangkan. Keempat kompetensi itu adalah kompetensi pedagogik, kompetensi profesional, kompetensi sosial dan kompetensi kepribadian. Untuk menguasai keempat kompetensi tersebut para guru harus mengikuti berbagai macam pelatihan kompetensi tersebut. Sebab. Guru yang mengikuti pelatihan dan pengembangan saja belum tentu bisa apalagi yang tidak pernah mengikuti dan mengembangkan kompetensinya.

Atas dasar asumsi itulah maka Kepala Sekolah MAN I Tanjung Pandan memberikan kebebasan kepada para guru untuk mengembangkan kompetensi ilmunya masing-masing. Diantaranya dengan cara diikutkan menjadi peserta pelatihan-pelatatihan berbagai potensi serta diberikan keleluasaan untuk melanjutkan studi lagi sesuai dengan bidang ilmunya masing-masing ${ }^{5}$.

Agar dapat mengetahui perbedaan antar komponen observasi dapat dilihat pada Tabulasi di Bawah ini:

\begin{tabular}{|c|c|c|c|c|c|}
\hline \multirow[t]{2}{*}{ NO } & \multirow{2}{*}{$\begin{array}{c}\text { NAMA } \\
\text { LEMBAGA }\end{array}$} & \multirow{2}{*}{$\begin{array}{c}\text { OBYEK } \\
\text { OBSERVASI }\end{array}$} & \multirow[t]{2}{*}{ RESPONDEN } & \multicolumn{2}{|c|}{$\begin{array}{c}\text { HASIL } \\
\text { JAWABAN }\end{array}$} \\
\hline & & & & Ya & Tidak \\
\hline & \multirow{9}{*}{$\begin{array}{l}\text { MAN I } \\
\text { Tanjung } \\
\text { Pandan } \\
\text { Belitung }\end{array}$} & \multirow{2}{*}{$\begin{array}{l}\text { Ada intruksi } \\
\text { melanjutkan } \\
\text { Study }\end{array}$} & Guru & $90 \%$ & $10 \%$ \\
\hline & & & Siswa & $100 \%$ & $0 \%$ \\
\hline & & \multirow{2}{*}{$\begin{array}{l}\text { Dianjurkan } \\
\text { mengikuti } \\
\text { kegiatan karya } \\
\text { ilmiah }\end{array}$} & Guru & $80 \%$ & $20 \%$ \\
\hline & & & Siswa & $83,3 \%$ & $16,7 \%$ \\
\hline & & \multirow{2}{*}{$\begin{array}{l}\text { Mengadakan } \\
\text { atau mengutus } \\
\text { pengembangan } \\
\text { kompetensi }\end{array}$} & Guru & $90 \%$ & $10 \%$ \\
\hline & & & Siswa & $83,3 \%$ & $16,7 \%$ \\
\hline & & $\begin{array}{l}\text { Perintah } \\
\text { mengadakan dan } \\
\text { mengembangkan } \\
\text { penelitian }\end{array}$ & Guru & $90 \%$ & $10 \%$ \\
\hline & & \multirow{2}{*}{$\begin{array}{l}\text { Ada kelompok } \\
\text { diskusi ilmiah }\end{array}$} & Guru & $80 \%$ & $20 \%$ \\
\hline & & & Siswa & $73,3 \%$ & $26,7 \%$ \\
\hline
\end{tabular}

\section{Implementasi Manajemen Kurikulum}

1. Guru Bebas Mengembangkan Kurikulum

Di Madrasah Aliyah Negeri I Tanjung Pandan selalu mengikuti setiap perubahan - perubahan yang ada dalam Kurikulum. Sehingga setiap kebijakan kurikulum yang dilaksanakan oleh pemerintah selalu diikuti dengan senang hati. Seperti saat ini,

${ }^{5}$ Dra. Nunung S, Kepala Sekolah Madrasah Aliyah Negeri I Tanjung pandan, Wawancara, pada tanggal 4 juni 2016 pukul 10.00 di Ruang Kepala Sekolah. 
kebijakan pemerintah adalah menggunakan kurikulum 2013 atau yang biasa di kenal dengan istilah K-13 maka semua guru di sinipun mengembangkan kurikulum 2013.

Berdasarkan lembar observasi tertutup yang diberikan kepada para Guru, semuanya mengatakan bahwa para guru di MAN I Tanjung Pandan ini diberikan kebebasan oleh Kepala Sekolahnya untuk mengembangkan kurikulumnya ${ }^{6}$. Dengan demikian, prinsip menejemen kurikulum yang dilakukan di sekolah ini menggunakan prinsip manajemen yang produktivitas ${ }^{7}$, demokratis ${ }^{8}$ dan kooperatif ${ }^{9}$. Sehingga kurikulum dapat berfungsi dengan baik sesuai dengan yang diharapkan oleh para peserta didik. Karena menurut Dr. Rusman, M.Pd, setidaknya ada enam fungsi manajemen kurikulum yang terus dikembangkan yaitu: meningkatkan efisisensi pemanfaatan sumber daya kurikulum, meningkatkan keadilan dan kesempatan pada siswa untuk mencapai hasil yang maksimal, meningkatk relevansi dan efektivitas pembelajaran sesuai dengan kebutuhan peserta didik maupun lingkungan sekitar peserta didik, meningkatkan efektivitas kinerja guru maupun aktivitas siswa dalam mencapai tujuan pembelajaran, meningkatkan efisiensi dan efektivitas proses belajar mengajar, dan meningkatkan partisipasi masyarakat untuk membantu mengembangkan kurikulum ${ }^{10}$. Agar para guru mengetahui dan paham tentang kurikulum atau perubahan kurikulum yang dilaksanakan oleg pemerintah maka setiap guru bidang studi diberikan keleluasaan untuk mengikuti pelatihanpelatihan kurikulum tewrbaru. Sehingga model kurikulum yang dilakukan di sekolah ini selalu sesuai dengan perubahan zaman.

\section{Target Kurikulum Selalu Tercapai}

Salah satu indikasi suksesnya proses belajar mengajar dalam suatu bidang ilmu pengetahuan adalah tercapainya target atau sasaran yang telah direncanakan baik melalui visi misi lembaga, silabus ataupun satuan acara pembelajaran. Kesuksesan pembelajaran tersebut dapat dilihat dari aspek guru maupun muridnya. Bagi guru kesuksesan dapat dilihat dari target kurikulum yang diajarkan tercapai semua atau tidak. Sedangan pada peserta didik lebih mengedepankan pada hasil pembelajarannya.

Atas dasar asumsi di atas maka peneliti megadakan survei sekaligus observasi secara tertutup berupa chek list ${ }^{11}$. Hasilnya bahwa semua guru mata pelajaran menyatakan telah berhasil menjalankan pembelajarannya. Mereka telah mengajar sesuai dengan target atau standar kelululusan yang telah ditentukan dalam RPP. Untuk memastikan apakah benar target kurikulum sudah tercapai maka peneliti mengecek kebenarannya kepada para peserta didik melalui observasi tertutup. Hasilnya menyatakan bahwa mereka membenarkan bahwa target kurikulum sudah selesai. Hanya saja ketika ditelusuri tentang keberhasilan pemahamannya terhadap

${ }^{6}$ Observasi tertutup kepada para guru MAN I Tanjung Pandan Belitung di ruang Guru, pada tanggal 4 Juni 2016, pukul 10 WIB.

${ }_{7}$ Menurut Dr. Rusman, M.Pd yang dimasud dengan produktifitas disini adalah hasil yang akan diperoleh dalam kegiatan kurikulum merupakan aspek yang harus dipertimbangkan dalam manajemen kurikulum. (lihat dalam bukunya Manajemen Kurikulum, Rajawali Pers, Jakarta, 2012. Hlm. 4)

8 Pelaksanaan manajemen kurikulum harus berasaskan demokrasi yang menempatkan pengelola, pelaksana dan subyek didik pada posisi yang seharusnya dalam melaksanakan tugas dengan penuh rasa tanggung jawab untuk mencapai tujuan kurikulum. (Dr. Rusman, M.Pd, Manajemen...........hlm.4)

9 Untuk memperoleh hasil yang diharapkan dalam kegiatan manajeman kurikulum perlu adanya kerjasama yang positif dari berbagai pihak. (Dr.Rusman, M.Pd, Manajemen........hlm.4)

${ }^{10}$ Lihat dalam bukunya Manajemen Kurikulum. hlm 5

${ }^{11}$ ObservaSI tertutup yang disebarkan kepada para guru dan siswa di MAN I Tanjung Pandan Belitung pada tanggal 3 Juni 2016, pukul 9.00 WIB. 
ilmu yang disampaikan mereka rata-rata baru mencapai $80 \%$. Namun demikian hasil tersebut sudah mencapai target standar kelulusan. Tinggi rendahnya Prosentase keberhasilan kelulusan tersebut tergantung pada tingkat kesulitan mata pelajaran yang diampu. Ada mata pelajaran yang tingkat kesulitannya rendah maka prosentase keberhasilannya tinggi sementara untuk mata pelajaran yang tingkat kesulitannya tinggi maka porsentase tingkat kelulusannya rendah.

Agar dapat mengetahui perbedaan antar komponen observasi dapat dilihat pada tabulasi di bawah ini:

\begin{tabular}{|c|c|c|c|c|c|}
\hline \multirow[t]{2}{*}{ NO } & \multirow{2}{*}{$\begin{array}{c}\text { NAMA } \\
\text { LEMBAGA }\end{array}$} & \multirow{2}{*}{$\begin{array}{c}\text { OBYEK } \\
\text { OBSERVASI }\end{array}$} & \multirow[t]{2}{*}{ RESPONDEN } & \multicolumn{2}{|c|}{$\begin{array}{c}\text { HASIL } \\
\text { JAWABAN }\end{array}$} \\
\hline & & & & Ya & Tidak \\
\hline \multirow[t]{7}{*}{$\overline{1}$} & \multirow{7}{*}{$\begin{array}{l}\text { MAN I } \\
\text { Tanjung } \\
\text { Pandan } \\
\text { Belitung }\end{array}$} & $\begin{array}{l}\text { Wajib } \\
\text { mengembangkan } \\
\text { kurikulum }\end{array}$ & Guru & $90 \%$ & $10 \%$ \\
\hline & & \multirow{2}{*}{$\begin{array}{l}\text { Kurikulum } \\
\text { disesuaikan } \\
\text { dengan kebutuhan } \\
\text { siswa }\end{array}$} & Guru & $90 \%$ & $10 \%$ \\
\hline & & & Siswa & $83,3 \%$ & $16,7 \%$ \\
\hline & & \multirow{2}{*}{$\begin{array}{l}\text { Ada visi dan misi } \\
\text { sekolah }\end{array}$} & Guru & $100 \%$ & $0 \%$ \\
\hline & & & Siswa & $100 \%$ & $0 \%$ \\
\hline & & $\begin{array}{l}\text { Kurikulum sesuai } \\
\text { dengan visi dan } \\
\text { misi sekolah }\end{array}$ & Guru & $83,3 \%$ & $16,7 \%$ \\
\hline & & $\begin{array}{l}\text { Target kurikulum } \\
\text { selalu tercapai }\end{array}$ & Guru & $90 \%$ & $10 \%$ \\
\hline
\end{tabular}

D. Implementasi Manajemen Sumber Pembelajaran

1. Guru Bebas Memiliki Sumber Pembelajaran

Hasil survei dan observasi sebanyak $80 \%$ guru mengatakan bahwa mereka bebas memiliki sumber pembelajaran. Artinya, guru yang mengajar di sekolah MAN I Tanjung Pandan Belitung ini tidak terjebak dengan sumber pembelajaran yang kaku. Jika guru diberikan kebebasan mencari sumber pembelajaran maka wawasan yang dimiliki guru akan sangat luas. Bila wawasan guru luas maka berbahagialah para siswanya, karena akan mendapatkan ilmu yang luas juga. Berbeda jika guru hanya terpatri dengan kurikulum atau sumber pembelajaran tunggal, maka bukan hanya siswanya yang merugi maka gurunya pun tidak mendapatkan tambahan ilmu sama sekali. Hanya saja sumber pembelajaran tersebut bukan didapatkan dari lembaga akan tetapi nerkat hasil usaha para guru sendiri. Hal ini membuktikan bahwa para guru tersebut memiliki keuletan dan kegigihan yang kuat untuk memperdalam dan meningkatkan kompetensi pedagogis dan profesinya.

2. Media Pembelajaran Berbasis Tehnologi

Sebenarnya salah satu gerbang ilmu pengetahuan yang tiada batasnya adalah jika media pembelajaran yang ada di sekolah tersebut sudah berbasis tehnologi. Sebab, dalam kurikulum 2013 media berbasis tehnologi menjadi wajib karena ada pencarian referensi melalui media berbasis tehnologi. Ketika peneliti observasi lansung di MAN I Tanjung Pandan, media pembelajaran berbasis tehnologi ini sudah berjalan, karena adanya fasilitas wifi atau internet yang memadai di setiap kelasnya. Hal ini sesuai dengan hasil wawancara dengan kepala sekolah, ia mengatakan bahwa wifi di sekolah ini sudah bisa di akses di setiap kelas. Sehingga penelusuran pemeblajaran bisa melalui web-web melalui google atau yahoo. 
Agar dapat mengetahui perbedaan antar komponen observasi dalam mengimplementasikan manajemen sumber dan media pembelajaran maka dapat dilihat pada tabulasi prosentase berikutr ini:

\begin{tabular}{|c|c|c|c|c|c|}
\hline \multirow[t]{2}{*}{ NO } & \multirow{2}{*}{$\begin{array}{c}\text { NAMA } \\
\text { LEMBAGA }\end{array}$} & \multirow{2}{*}{$\begin{array}{c}\text { OBYEK } \\
\text { OBSERVASI }\end{array}$} & \multirow[t]{2}{*}{ RESPONDEN } & \multicolumn{2}{|c|}{$\begin{array}{c}\text { HASIL } \\
\text { JAWABAN }\end{array}$} \\
\hline & & & & Ya & Tidak \\
\hline \multirow[t]{4}{*}{1} & \multirow{4}{*}{$\begin{array}{l}\text { MAN I } \\
\text { Tanjung } \\
\text { Pandan } \\
\text { Belitung }\end{array}$} & \multirow{2}{*}{$\begin{array}{l}\text { Perpustakaan } \\
\text { sekolah } \\
\text { memadai }\end{array}$} & Guru & $90 \%$ & $10 \%$ \\
\hline & & & Siswa & $90 \%$ & $10 \%$ \\
\hline & & \multirow{2}{*}{$\begin{array}{l}\text { Ada Media } \\
\text { pembelajaran } \\
\text { yang berbasis } \\
\text { tehnologi }\end{array}$} & Guru & $100 \%$ & $0 \%$ \\
\hline & & & Siswa & $100 \%$ & $0 \%$ \\
\hline
\end{tabular}

\section{E. Implementasi Manajemen Sarana dan Prasarana}

1. Fasilitas Pembelajaran Memadai

Fasilitas pemeblajaran di sekolah ini sudah cukup memamadai, karena sudah dilengkapi berbagai media dan sarana pembelajaran. Misalnya untuk pembelajaran yang memerlukan akses internet para siswa sudah bisa mengakses internet di kelasnya masing-masing melalui wifi. Begitu juga dengan laboratorium, di sekolah ini sudah tersedia labaoratorium Bahasa dan Lab Komputer. Untuk laboratorium IPA sedang dalam proses pembangunan.

Begitu juga dengan fasilitas untuk pembelajaran olah raga, sekolah ini sudah memiliki beberapa lapangan olah raga sperti lapangan futsal, lapangan Volly dan Tenis Meja. Sementara untuk lapangan sepak bola dan Basket belum ada karena keterbatasan lokasinya.

\section{Sekolah Memiliki Data Base Sarana dan Prasarana}

Semua data atau sarana dan prasarana yang ada di MAN I Tanjung Pandan sudah terdata melalui data inventaris yang dibuat oleh TU sekolah. Dengan demikian semua alat, fasilitas yang ada terkontrol dengan baik oleh pihak sekolah. Hal ini bertujuan agar semua fasilitas atau sarana dan prasarana tercatat dengan baik, sehingga akan memudahkan pencarian serta perawatan.

Sarana dan prasarana yang ada di Madrasah Aliyah Nurul Falah dan Madrasah Al-Muhajirin Koba Bangka Tengah belum selengkap seperti yang ada di MAN I Tanjung Pandan. Sebab, kedua lembaga ini memiliki keterbatasan biaya dari pemerintah karena berstatus swasta. Namun demikian, usaha dari setiap pimpinannya terus menerus mengupayakan penyempurnaan sarana dari tahun ketahunnya. Hal ini terbukti dengan bukti fisik dan fasilitas lainnya yang darin tahun ke tahun selalu mengalami peningkatan.

Untuk melihat perbedaan antar komponen yang diobservasi maka dapat di lihat pada tabulasi yang tercantum di bawah ini: 


\begin{tabular}{|c|c|c|c|c|c|}
\hline \multirow[t]{2}{*}{ NO } & \multirow{2}{*}{$\begin{array}{c}\text { NAMA } \\
\text { LEMBAGA }\end{array}$} & \multirow{2}{*}{$\begin{array}{c}\text { OBYEK } \\
\text { OBSERVASI }\end{array}$} & \multirow[t]{2}{*}{ RESPONDEN } & \multicolumn{2}{|c|}{$\begin{array}{c}\text { HASIL } \\
\text { JAWABAN }\end{array}$} \\
\hline & & & & Ya & Tidak \\
\hline \multirow[t]{8}{*}{1} & \multirow{8}{*}{$\begin{array}{l}\text { MAN I } \\
\text { Tanjung } \\
\text { Pandan } \\
\text { Belitung }\end{array}$} & \multirow{2}{*}{$\begin{array}{l}\text { Pengadaan } \\
\text { sarana dan } \\
\text { prasarana } \\
\text { direncanakan } \\
\text { tiap tahun }\end{array}$} & Guru & $100 \%$ & $0 \%$ \\
\hline & & & Siswa & $93,3 \%$ & $6,7 \%$ \\
\hline & & \multirow{2}{*}{$\begin{array}{l}\text { Semua sarana } \\
\text { dan prasarana } \\
\text { terpelihara } \\
\text { dengan baik }\end{array}$} & Guru & $90 \%$ & $10 \%$ \\
\hline & & & Siswa & $93,3 \%$ & $6,7 \%$ \\
\hline & & \multirow{2}{*}{$\begin{array}{l}\text { Sarana dan } \\
\text { prasarana } \\
\text { sudah } \\
\text { mencukupi }\end{array}$} & Guru & $80 \%$ & $20 \%$ \\
\hline & & & Siswa & $73,3 \%$ & $26,7 \%$ \\
\hline & & \multirow[t]{2}{*}{$\begin{array}{l}\text { Ada inventaris } \\
\text { sarana dan } \\
\text { prasarana }\end{array}$} & Guru & $100 \%$ & $0 \%$ \\
\hline & & & Siswa & $93,3 \%$ & $6,7 \%$ \\
\hline
\end{tabular}

\section{F. Peluang dan Hambatan dalam Mengimplementasikan Manajemen Mutu Pendidikan Islam}

1. Faktor Peluang

a. Kepemimpinan yang Demokratis

Berdasarkan hasil observasi yang dilakukan peneliti di ketiga lembaga yaitu MAN I Tanjung Pandan Belitung, di Madrasah Aliyah Nurul Falah Air Mesu Pangkalan Baru dan di Madrasah Aliyah Al-Muhajirin Koba Bangka Tengah menunujukkan bahwa gaya kepemimpinannya Demokratis. Hal ini terbukti hasil data observasi tertutup rata-rata prosentasenya di atas $70 \%$ baik hasil yang ditujukan kepada guru maupun kepada siswa.

Gaya kepemimpinan yang demokratis ini menjadi peluang yang baik untuk meningkatkan manajemen lembaga yang bermutu. Sebab, untuk meningkatkan mutu pendidikan diperlukan pemimpin yang transfaran atau open mamagement. Dengan demikian para guru dan staf yang lainnya akan menjadi sungguhsungguh dalam meningkatkan kualitas atau kompetensinya masing-masing. Semakin tinggi tingkat kerjasama dan proses yang dilakukan dalam suatu lembaga maka akan berpengaruh sangat signifikan juga kepada peningkatan mutu pendidikan lembaganya demikian juga jika sebaliknya ${ }^{12}$.

Hal ini disebabkan salah satu syarat untuk meningkatkan manajemen mutu pendidikan yang baik adalah adanya peningkatan partisipasi. Peningkatan

${ }^{12}$ Hal ini sesuai dengan yang dikatakan H.M.Hasbullah, kualitas atau mutu lembaga pendidikan menyangkut dua dimensi yaitu dimensi proses dan dimensi hasil (output). Mutu proses diukur dari indikator mutu komponen dan interaksi antar kompnen (Kepala Sekolah, Guru dan Staf). Sedangkan mutui hasil diukur dari indikator capaian skor prestasi lulusan baik yang menyangkut akademik maupun non kademik. (lihat lebih jauh pada bukunya yang berjudul "Kebijakan Pendidikan dalam Perspektif Teori, Aplikasi, dan Kondisi Obyektif Pendidikan di Indonesia", Rajawali pers, Jakarta, 2015, hlm.19). 
partisipasi yang dimaksud adalah menciptakan lingkungan yang terbuka dan demokratik. Dimana warga sekolah (Guru, Murid dan karyawan) dan masyarakat (orang tua murid, tokoh masyarakat, usahawan, ilmuwan, dsb) didorong untuk terlibat secara langsung dalam penyelenggaraan pendidikan, mulai dari pengambilan keputusan, pelaksanaan dan evaluasi pendidikan yang diharapkan dapat meningkatkan mutu pendidikan ${ }^{13}$. Dengan demikian jika semua warga sekolah dan masyrakat dilibatkan maka akan merasa memiliki. Ketika merasa memiliki maka akan dengan senang hati berusaha untuk meningkatkan mutu pendidikan secara bersama-sama.

b. Kedisiplinan yang Baik

Salah satu indikator lembaga pendidikan yang baik adalah kedisiplinan. Bila dalam lembaga pendidikan kedisiplinannya baik maka akan baik juga lembaganya. Dengan kata lain kedisiplinan dalam suatu lembaga pendidikan adalah indikasi utamanya. Berdasarkan hasil observasi langsung peneliti di tiga lembaga yaitu di MAN I Tanjung Pandan Belitung, telah menrepkan kedisiplinan. Hal ini dikarenakan di lembaga tersebut kedisipninan bukan hanya dituangkan secara lisan akan tetatpi sudah berupa tulisan (Surat Keputusan tentang tata tertib dan kode etik guru).

Atas dasar itulah maka peneliti dapat menyimpulkan bahwa kedisiplinan yang ada di tiga lembaga ini merupakan peluang besar untuk meningkatkan kualitas pendidikan. Hal ini sesuai dengan hasil observasi tertutup yang disebarkan kepada guru dan siswa yang ada rata-rata di atas $75 \%$ jawaban tentang kedisiplinannya.

c. Usaha Perbaikan Sarana dan Prasarana

MAN I Tanjung Pandan termasuk lembaga yang sangat serius memperbaiki dan meningkatkan sarana dan prasarananya. Hal ini disebabkan lembaga tersebut statusnya negeri, sehingga biaya yang dibutuhkan langsung bisa didapatkan melalui APBD maupun APBN walaupun secara bertahap. Berbeda dengan Madrasah Aliyah Nurul Falah dan Madrasah Aliyah AlMuhajirin karena swasta maka sarana dan prasarananya masih belum selengkap MAN I Tanjung Pandan. Namun demikian, semangat untuk meningkatkan sarana dan prasarananya maka tiap tahun selalu ada peningkatan.

d. Tekad atau Motivasi Pengembangan SDM yang baik

Lembaga pendidikan yang baik adalah lembaga yang tidak pernah puas dengan hasil pendidikan yang biasa, akan tetapi selalu berusaha untuk mendapatkan hasil pendidikan yang luar biasa. Untuk itu, salah satu faktor agar hasil pendidikan mendapatkan hasil yang baik yaitu tergantung pada sumber daya manusia (SDM). Jika pengembangan SDM selalu dilakukan pengembangan secara berkesinambungan maka maka SDMnya akan memiliki kompetensi yang dapat diunggulkan.

Berdasarkan hasil observasi peneliti di MAN I Tanjung Pandan memiliki tekad dan motivasi yang kuat dalam mengembangkan kualitas SDMnya. Khususnya yang dilakukan di MAN I Tanjung Pandan, Kepala Sekolah selalu mengingatkan dan menganjurkan agar para guru dan staf selalu mengembangkan kompetensinya masing-masing. Adapun cara pengembangannya bisa studi lanjut atau dengan cara mengikuti pelatihanpelatihan yang ada korelasinya dengan potensi diri masing-masing. Dengan demikian SDM yang dimiliki oleh MAN I Tanjung Pandan benar-benar

${ }^{13}$ Prof. Dr. Veithzal Rivai Zainal, dkk, Islamic Quality Education Management, pentingnya mengelola pendidikan bermutu untuk melahirkan manusia unggul menurut islam, serta mencerdaskan umat dengan pendidikan bermutu dan islami, PT.Gramedia pustaka Utama, Jakarta, 2016, hlm.76 
memiliki kompetensi yang mumpuni sesuai dengan bidang keilmuannya masing-masing.

Tekad dan motivasi inilah yang nantinya menjadi peluang besar untuk meningkatkan mutu pendidikan di lembaganya dan khususnya mutu pendidikan yang berada di lembaga pendidikan Islam. Jika niat baik tersebut terus dikembangkan dan dimanaj dengan baik, maka opini tentang SDM di lembaga pendidikan islam rendah akan hilang. Sebab, kunci utama kualitas pendidikan termasuk terletak pada kekuatan SDMnya. Jika memiliki SDM yang unggul maka akan muncul kreasi dan inovasi mutu pendidikan yang unggul pula.

e. Sistem dan Metode Pembelajaran yang Humanis

Saat ini sudah bukan masanya lagi bahwa guru merupakan super power atau super man atau pun super hebat. Sehingga guru tidak lagi kaku atau monoton dengan cara pengajaran yang bukan saja menjadi beban bagi siswanya akan tetapi juga menjadio beban bagi dirinya. Seperti yang terjadi pada Guru tempo dulu, dimana seorang guru bagaikan dewa yang memiliki kuasa penuh dan memiliki dan menguasai ilmu segalanya. Sehingga model pembelajarannya sangat tidak komunikatif karena murid hanya bagaikan gelas atau botol kosong yang harus siap diisi apa saja oleh sang guru. Tidak ada diskusi atau tidak ada tanya jawab sama sekali, bahkan jika ada yang bertanya menjadi ancaman sendiri bagi para siswanya. Model pembelajaran seperti ini biasa disebut dengan model pembelajaran otoriter bahkan diktator. Sehingga guru tidak memberikan kesempatan sama sekali pada siswa untuk bebas berkarya dan berkreasi karena selalu diintimidasi. Berdasarkan hasil observasi peneliti di ketiga lembaga yang diobservasi yaitu MAN I Tanjung Pandan, tidak ditemukan lagi model Guru yang mengajar dengan sistem atau metode otoriter dan diktator. Rata-rata para guru sudah cair dalam mengajar, yakni sudah ada komunikasi yang baik antara siswa dan guru. Dengan demikian model pembelajarannya sudah humanis, yaitu sudah memanusiakn manusia.

Melalui model atau metode pembelajaran yang humanis inilah termasuk salah stu peluang besar untuk mejadikan para siswa yang unggul. Yaitu siswa yang memiliki intelektual yang luas karena diberikan kebebasan untuk menggali potensi atau bakatnya secara bebas. Dengan catatan pembinaan atau pengembangan potensi intelektual atau bakat siswa dibina dengan cara yang sistematis sesuai dengan kurikulum yang berlaku.

\section{f. Motivasi Pencarian Referensi Multi Media}

Salah satu indikasi lembaga yang baik adalah memiliki sumber belajar yang lengkap, selain perpustakaan manual juga memiliki perpustakaan digital. Bahkan referensi bukan hanya didapatkan dari media cetak saja akan tetapi juga bisa didapatkan melalui media elektronik atau media yang berbasis tehnologi dan informasi.

Dari ketiga lembaga yang di observasi oleh peneliti, yang sudah memiliki kriteria tersebut baru di MAN I Tanjung Pandan. Namun demikian, motivasi yang kuat untuk menuju ke arah sarana media yang berbasis sains dan tehnologi juga sedang dilakukan oleh MA Nurul falah dan MA Al-Muhajirin Koba Bangka Tengah. Dengan demikian motivasi ini menjadi peluang yang besar bagi dunia pendidikan islam yang ada di lembaga ini untuk menjadi lembaga yang memiliki basis tehnologi dan informasi sehingga akan siap berkompetisi di era Globalisasi saat ini.

2. Faktor Penghambat

a. Pendanaan yang terbatas

Sudah menjadi rahasia umum jika dana merupakan faktor penting dalam mengembangkan berbagai sarana dalam lembaga pendidikan baik itu sarana 
fisik maupun non fisik. Terlebih jika lembaga tersebut berada pada status swasta yang mengandalan dana swadaya bukan dana pemerintah. Inilah penyebab alasan atau kendala utama yang dirasakan disetiap lembaga yang memiliki keterbatasan dana.

Berdasarkan observasi peneliti masalah dana ini bukan hanya menjadi kendala di swasta saja akan tetapi di lembaga negeri juga merasakan hal yang sama. Artinya, jika di lembaga yang notabene berlabel negeri saja masih merasakan kekurangan dan keterbatasan dana untuk mengembangkan sarana dan prasarana, apalagi yang terjadi pada lembaga pendidikan swasta. Sehingga dengan keterbatasan inilah akhirnya kelengkapan fasilitas pendidikan menjadi terhambat

b. Sarana dan Prasarana yang Belum Memadai

Sarana dan prasarana yang ada dalam suatu lembaga termasuk indikasi kualitas pendidikan yang ada di lembaga tersebut. Untuk itu, jika semakin lengkap sarana dan prasarana sekolah tersebut maka akan semakin baik pula cerminan kualitas pendidikan di sekolah tersebut. Hanya saja, sarana prasarana yang ada di MAN I Tanjung Pandan masih terkendala di laboratorium MIPA. Namun demikian pada tahun berikiutnya sudah mulai dilengkapi. Dengan demikian di tahun berikutnya di MAN I Tanjung Pandan sarana dan prasarananya mulai memadai.

c. Biaya Studi Lanjut yang Terbatas

Tidak satu pun guru yang tidak ingin melanjutkan studinya di S2. Namun demikian kendala yang ada di MAN I Tanjung Pandan, adalah masalah biaya pendidikannya. Dengan demikian, pengembangan kompetensi ilmu yang ada di madrasah tersebut akan tertinggal dengan lembaga-lembaga lain yang memiliki suport atau donator biaya pendidikan bagi para guru. Hal ini pada akhirnya akan menjadi salah satu kendala untuk meningkatakan mutu pendidikan yang berbasis madrasah. Probematika ini pada akhirnya menjadi problem yang sama yang terjadi di setiap madarasah-madrasah yang di kelola baik yang negeri maupun yang swasta.

\section{DAFTAR PUSTAKA}

Mulyasa, Menjadi Guru Profesional, Bandung: Remaja Rosdakarya, Cet. III, 2005

Muhaimin, Arah Baru Pengembangan Pendidikan Islam, Pemberdayaan Pengembangan Kurikulum Hingga Redefinisi Islamisasi Pengetahuan, Bandung: Nuansa, 2003

Danim, S., Visi Baru Manajemen Sekolah dari Unit Birokrasi ke Lembaga Akademik. Jakarta: Bumi Aksara, 2006

Edward Sallis. Total Quality Management in Education. New Jersey: Prentice-Hall, Inc. 1993

Bill Creech. Winning the Quality War. In World Executive's Digest. Juli 1996

Kamus Kontemporer Al-Asriy, Yayasan Ali Maksum, Ponpes Krapyak, Yogyakarta, Cet. Ke 4, 1998

Malayu SP Hasibuan, Manjemen Dasar dan Pengertian, Jakarta Gunung Agung, 1996

Hasibuan, Manajemen Pendidikan di Indonesia, Bina Aksara, Jakarta 1988

Oemar Hamalik, Dasar-Dasar Pengembangan Kurikulum, Bandung: PT. Remaja Rosdakarya, 2007

47| EDUGAMA Vol.01 No.01 Juli 2017 
West-Burnham, J. 1997. Managing Quality in Schools, London : Prentice-Hall

Goetsch, D.L \& Davis S. 1995, Implementing Total Quality, Englewood,Cliffis, New Jersy ; Prentice Hall International, Inc.

Muhammad Abdullah Al Buraey, Management \&Administarsi Islam, Associate Professor of Managemen Chairman, Management Development Program College Industrial Management, King Fahd University Of Petroleum \& Mineral, saudi Arabia, 1990.

Hasan Langgulung, Pendidikan dan Peradaban Islam Suatu Analisa Sosio-Psikologi, Pustaka Al Husna, jakarta, Cet ke3, 1985

Sugiono, Memahami Penelitian Kualitatif, Bandung: Alfabta, 2005

Dokumentasi Madrasah Aliyah Negeri Tanjung Pandan, Belitung, Kabupaten Belitung, Tahun 2016

Mc. Conkey Dale D, Manajemen Bagi Organisasi non Perusahaan, Terj. M.Mas'ud Jakarta, Pustaka Binaman, 1982

Dr. Rusman, M.Pd, Manajemen Kurikulum, Rajawali Pers, Jakarta, 2012

H.M.Hasbullah, Kebijakan Pendidikan dalam Perspektif Teori, Aplikasi, dan Kondisi Obyektif Pendidikan di Indonesia", Rajawali pers, Jakarta, 2015

Prof. Dr. Veithzal Rivai Zainal, dkk, Islamic Quality Education Management, pentingnya mengelola pendidikan bermutu untuk melahirkan manusia unggul menurut islam, serta mencerdaskan umat dengan pendidikan bermutu dan islami, PT.Gramedia pustaka Utama, Jakarta, 2016 